\title{
Effect of Saccharification Methods on Bioethanol Production by Thermophiles from Eichhornia crassipes
}

\author{
Preetha Ganguly ${ }^{1}$, Chetna Gangwar ${ }^{1}$, Anurag Mishra ${ }^{1}$, Rosy Rani ${ }^{2}$, Shashank Awasthi ${ }^{2}$, \\ Ravi Kant Singh ${ }^{1}$ and Tripti Bhatnagar ${ }^{2 *}$ \\ ${ }^{1}$ Noida Institute of Engineering and Technology, Greater Noida, India \\ ${ }^{2}$ Codon Biotech Pvt. Ltd., Noida, India \\ *Corresponding author
}

\section{A B S T R A C T}

\section{Keywords}

Water hyacinth,

Pre-treatment,

Fermentation,

Bioethanol

\section{Article Info}

Accepted:

28 January 2018

Available Online:

10 February 2018

\begin{abstract}
Water hyacinth (Eichhornia crassipes) represents a promising candidate for fuel ethanol production in tropical countries because of their high availability and high biomass yield. Bioconversion of such biomass to bioethanol could be wisely managed through proper technological approach. In this work, water hyacinth was used as a substrate for bioethanol production by the use of thermophiles. Water hyacinth was pretreated with sulfuric acid (1 M) and sodium hydroxide (1M) for release of free sugars. Acid pretreatment was most effective in comparison to alkali treatment that resulted in formation of $1.73 \mathrm{mg} / \mathrm{ml}$ reducing sugar. The sugars after pretreatment produced maximum $4.1 \mathrm{gm} / 1$ ethanol by Bacillus vietnamensis strain and $3.58 \mathrm{gm} / 1$ by Bacillus stearothermophilus. Thus, the experiment imparts an economic value to water hyacinth that are cleared from choking waterways.
\end{abstract}

\section{Introduction}

Global warming is a direct cause of overuse and continuous exploitation of fossil fuel resources. As a result there is an emerging need to utilize renewable, sustainable, cost effective, ecofriendly and green alternative energy sources (Chum., 2001). Lignocellulosic biomass can be used as an alternative energy producing source because of its abundance, availability and relatively low cost.

Bioethanol being a safe, clean and renewable resource, can be considered as a potential alternative to fossil fuel (Rezania et al., 2015). However, most of ethanol is mainly produced from either starch or sugar rich crops therefore it may raise land competition between the food production and biomass energy utilization which causes problems in a developing country like India (Das et al., 2015). Thus, waste or unused lignocellulose is considered as more attractive source for bioethanol production (Valentine et al., 2012; Bayrakci and Kocar, 2014). Ethanol also has a higher latent heat of vaporization $(855 \mathrm{MJ} / \mathrm{Kg})$ as compared to petrol $(293 \mathrm{MJ} / \mathrm{Kg})$. Ethanol has higher octane number (99) than that of petrol (80-100) (Ganguly et al., 2012) which 
makes ethanol a non-polluting and green fuel.

Vast number of waste and non-food lignocellulosic material has been experimented upon for production of ethanol. Water hyacinth or Eichhornia crassipes is a aquatic weed which causes major hazard as it grows uncontrolled in water bodies. Water hyacinth, which originated from Amazon basin is known as one of the world's most intractable and invasive weed (Hu. J et al., 2011) and is usually blamed for depleting nutrients and oxygen from water bodies, reducing biodiversity, increasing evapotranspiration leading to destruction of aquatic ecosystem (Malik, 2007; GuerreroCoronilla et al., 2015). Water hyacinth has a high hemicellulose content (30-55\% of dry weight) and can provide hemicellulose sugar for conversion to ethanol. The biomass of water hyacinth has a very low lignin $(3.5 \%)$ and high amount of hemicellulose (48\%) and 18\% cellulose content (Nigam, 2002). Also being an aquatic plant it has an advantage of not being in competition to food crops growing on land (Mishima et al., 2008).

\section{Materials and Methods}

\section{Microorganisms}

Pure Thermophillic bacterial strains Bacillus vietnamensis (N2) and Bacillus stearothermophilus (N3) were used for conversion of Lignocellulosic waste to ethanol.

\section{Saccharification of water hyacinth plant}

Water hyacinth was collected from Yamuna River. The water hyacinth plant was sundried for 3-4 days in sunlight. The dried parts of water hyacinth were powdered in a grinder. The powder was subjected to pretreatment with acid and alkali. 1N Sulphuric acid and $1 \mathrm{~N} \mathrm{NaOH}$ were added to $5 \mathrm{gm}$ each of dried plant material, respectively and incubated for $24 \mathrm{~h}$ at room temperature for hydrolysis to convert lignocellulosic waste into free sugar.

\section{Estimation of sugar}

Released sugar was estimated by using dinitrosalicylic acid (DNS) test, 3,5Dinitrosalicylic acid is an aromatic compound which reacts with reducing sugars and other reducing molecules to form 3-amino-5nitrosalicylic acid, that absorbs light strongly at $540 \mathrm{~nm}$ (Miller, 1959).

\section{Production of bioethanol by fermentation}

The fermentation media was prepared by addition of yeast extract $(0.2 \mathrm{gm})$, urea $(1 \mathrm{gm})$ and dextrose $(5 \mathrm{gm})$ into the pretreated Water Hyacinth samples t per $100 \mathrm{ml}$ of fermentation media. $10 \%$ thermophilic culture was inoculated in fermentation media. The mouths of the flasks were tightly sealed to maintain microaerobic condition and the fermentation was carried out at $50^{\circ} \mathrm{C}$ for 7 days and samples were taken from each of the two broths on each day for quantitative estimation of ethanol.

\section{Estimation of ethanol}

The concentration of ethanol was estimated using gas chromatography (GC) (Nucon engineer) with a flame ionization detector (FID) and $6 \mathrm{ft}$. Porapak $\mathrm{N}$ packed column $(80 / 100$ mesh) using nitrogen gas as the carrier. Flame is ignited at the flame ionization detector port. The injector, detector and oven temperatures were programmed. After reaching the stability, when the oven temperature and detector, injector temperature were at the programmed temperature, a sample is injected from fermentation flask into injector port by using a micro syringe $(1-10$ $\mu \mathrm{l})$. The oven temperature was held at $80^{\circ} \mathrm{C}$. The injector and detector temperature was 
maintained at $110^{\circ} \mathrm{C}$. External standard was applied for identification and quantification. The peak eluted is noted (using Nuchrome software) and by knowing the area of peak, the concentration of ethanol is calculated using calibration chart and the ethanol was determined in $\mathrm{g} / \mathrm{l}$.

\section{Results and Discussion}

Water Hyacinth sample was pretreated using Sulphuric acid and Sodium hydroxide. Among acid and alkali, acid was most effective in pretreatment because in acidic pretreatment more amount of sugar was released in comparing to alkali treatment presented in table 1 .

The two novel thermophiles which were provided from Codon Biotech Pvt. Ltd was 1- Bacillus vietnamensis (N2) and Bacillus stearothermophilus (N3), these cultures were used for bioethanol production.

\section{Estimation of bioethanol}

Fermentation was carried out for 7 days and sample was collected every day for estimation of ethanol by gas chromatoghraphy.

The Water Hyacinth sample which was treated with Sulphuric acid, produced maximum amount of ethanol i.e., $4.1 \mathrm{~g} / \mathrm{l}$ by strain $\mathrm{N} 2$ Bacillus vietnamensis on $4^{\text {th }}$ days (Table 2 and Fig. 1) and $3.58 \mathrm{gm} / 1$ by strain N3 Bacillus stearothermophilus on $5^{\text {th }}$ day (Table 3 and Fig. 2).

The Water Hyacinth sample which was treated with Sodium hydroxide, produced lesser amount of ethanol i.e., $2.12 \mathrm{~g} / \mathrm{l}$ by strain N3 Bacillus stearothermophilus on $2^{\text {nd }}$ day (Table 5 and Fig. 4) and $0.28 \mathrm{gm} / 1$ by strain N2 Bacillus vietnamensis on $3^{\text {rd }}$ day (Table 4 and Fig. 3).
Water Hyacinth is a highly problematic invasive species and it is one of the fastest growing plants known, water hyacinth reproduces primarily by way of runners or stolons which eventually form daughter plants. Each plant additionally can produce thousands of seeds each year, and these seeds can remain viable for more than 28 years.

When not controlled, water hyacinth will cover lakes and ponds entirely; this dramatically affects water flow, blocks sunlight from reaching native aquatic plants, and starves the oxygen of water, often killing fish.

In India the most easy and common method of removal of water hyacinth from water bodies is physical extraction of the plants from the water. Thus, these waste plants were selected as substrate for bioethanol production, which could result in production of economically important ethanol from waste plants.

Biofuel production from cellulosic materials greatly depends on the disruption of its complex lignocellulosic structure, which is recalcitrant to biodegradation.

Hence, a suitable and eff ective pretreatment method should be selected for different cellulosic substrates. Various kinds of pretreatment methods, including acid and alkali were used for cellulose hydrolysis. But in the present study acid gave the highest breakdown and related ethanol production.

According to Qiuzhuo Zhang et.al (2016) $1.289 \mathrm{~g} / \mathrm{L}$ bioethanol was achieved using sulfuric acid pretreated water hyacinth substrate. In another study by Kumari $\mathrm{N}$ et al., (2014) fermentation of water hyacinth hydrolysate using pentose fermenting yeast, Pichia stipitis yielded an ethanol concentration of $3.193 \mathrm{~g} / \mathrm{L}$. 
Table.1 Concentration of sugar obtained after pretreatment with acid and alkali

\begin{tabular}{|l|l|l|l|l|l|l|}
\hline $\mathbf{S}$. & $\begin{array}{l}\text { SAMPLE } \\
\text { NO }\end{array}$ & DNS & $\begin{array}{l}\text { POTESSIUM } \\
\text { SODIUM } \\
\text { TATRATE } \\
(\mathbf{m l})\end{array}$ & $\begin{array}{l}\text { DISTILLED } \\
\text { WATER } \\
(\mathbf{m l})\end{array}$ & O.D & $\begin{array}{l}\text { CONC. } \\
\text { OF } \\
\text { SUGAR } \\
(\mathbf{m g} / \mathbf{m l})\end{array}$ \\
\hline $\mathbf{1 .}$ & $\begin{array}{l}\text { Acid treated } \\
\text { Sample 1 }\end{array}$ & 2 & 1 & 6 & 1.35 & 1.73 \\
\hline $\mathbf{3 .}$ & $\begin{array}{l}\text { Acid treated } \\
\text { Sample 2 }\end{array}$ & 2 & 1 & 6 & 1.33 & 1.70 \\
\hline $\mathbf{4 .}$ & $\begin{array}{l}\text { Alkali treated } \\
\text { Sample 1 }\end{array}$ & 2 & 1 & 6 & 0.60 & 0.77 \\
\hline $\mathbf{5 .}$ & $\begin{array}{l}\text { Alkali treated } \\
\text { Sample 2 }\end{array}$ & 2 & 1 & 6 & 0.62 & 0.79 \\
\hline
\end{tabular}

Table. 2 Bioethanol production in water hyacinth treated with acid by strain N2

(Bacillus vietnamensis)

\begin{tabular}{|l|l|l|}
\hline S.NO & $\begin{array}{l}\text { DAYS OF } \\
\text { INCUBATION }\end{array}$ & $\begin{array}{l}\text { AMOUNT OF ETHANOL } \\
\text { PRODUCED in } \mathbf{~ g m / 1 ~}\end{array}$ \\
\hline $\mathbf{1}$ & $1^{\text {st }}$ & $0.65 \pm 0.01$ \\
\hline $\mathbf{2}$ & $2^{\text {nd }}$ & $1.32 \pm .2$ \\
\hline $\mathbf{3}$ & $3^{\text {rd }}$ & $1.39 \pm 0.32$ \\
\hline $\mathbf{4}$ & $\mathbf{4}^{\text {th }}$ & $\mathbf{4 . 1} \pm 0.22$ \\
\hline $\mathbf{5}$ & $5^{\text {th }}$ & $1.93 \pm 0.18$ \\
\hline $\mathbf{6}$ & $6^{\text {th }}$ & $1.62 \pm 0.22$ \\
\hline $\mathbf{7}$ & $7^{\text {th }}$ & $0.73 \pm 0.09$ \\
\hline
\end{tabular}

Table.3 Bioethanol production in water hyacinth treated with acid by N3

(Bacillus stearothermophilus)

\begin{tabular}{|l|l|l|}
\hline S. NO & DAYS & $\begin{array}{l}\text { Amount Of Ethanol } \\
\text { Produced in gm/l }\end{array}$ \\
\hline $\mathbf{1}$ & $1^{\text {st }}$ & $0.63 \pm 0.11$ \\
\hline $\mathbf{2}$ & $2^{\text {nd }}$ & $0.83 \pm 0.15$ \\
\hline $\mathbf{3}$ & $3^{\text {rd }}$ & $3.44 \pm 0.65$ \\
\hline $\mathbf{4}$ & $4^{\text {th }}$ & $3.24 \pm 0.48$ \\
\hline $\mathbf{5}$ & $5^{\text {th }}$ & $\mathbf{3 . 5 8} \pm 0.55$ \\
\hline $\mathbf{6}$ & $6^{\text {th }}$ & $1.27 \pm 0.21$ \\
\hline $\mathbf{7}$ & $7^{\text {th }}$ & $0.23 \pm 0.25$ \\
\hline
\end{tabular}


Table.4 Bioethanol production in water hyacinth treated with alkali by strain N2 (Bacillus vietnamensis)

\begin{tabular}{|l|l|l|}
\hline S.NO & DAYS & Amount Of Ethanol Produced in $\mathbf{g m} / \mathbf{l}$ \\
\hline $\mathbf{1}$ & $1^{\text {st }}$ & $0.06 \pm 0.01$ \\
\hline $\mathbf{2}$ & $2^{\text {nd }}$ & $0.09 \pm 0.01$ \\
\hline $\mathbf{3}$ & $3^{\text {rd }}$ & $\mathbf{0 . 2 8} \pm 0.011$ \\
\hline $\mathbf{4}$ & $4^{\text {th }}$ & $0.2 \pm 0.0$ \\
\hline $\mathbf{5}$ & $5^{\text {th }}$ & 0 \\
\hline
\end{tabular}

Table.5 Bioethanol production in water hyacinth treated with alkali by strain N3 (Bacillus stearothermophilus)

\begin{tabular}{|l|l|l|}
\hline S.NO & DAYS & $\begin{array}{l}\text { Amont Of Ethanol } \\
\text { Produced In gm/l }\end{array}$ \\
\hline $\mathbf{1}$ & $1^{\text {st }}$ & $1.55 \pm 0.14$ \\
\hline $\mathbf{2}$ & $2^{\text {nd }}$ & $\mathbf{2 . 1 2} \pm 0.18$ \\
\hline $\mathbf{3}$ & $3^{\text {rd }}$ & $1.84 \pm 0.12$ \\
\hline $\mathbf{4}$ & $4^{\text {th }}$ & $0.3 \pm 0.002$ \\
\hline $\mathbf{5}$ & $5^{\text {th }}$ & 0 \\
\hline
\end{tabular}

Fig.1 Amount of ethanol production vs days graph by N2 (Bacillus vietnamensis)

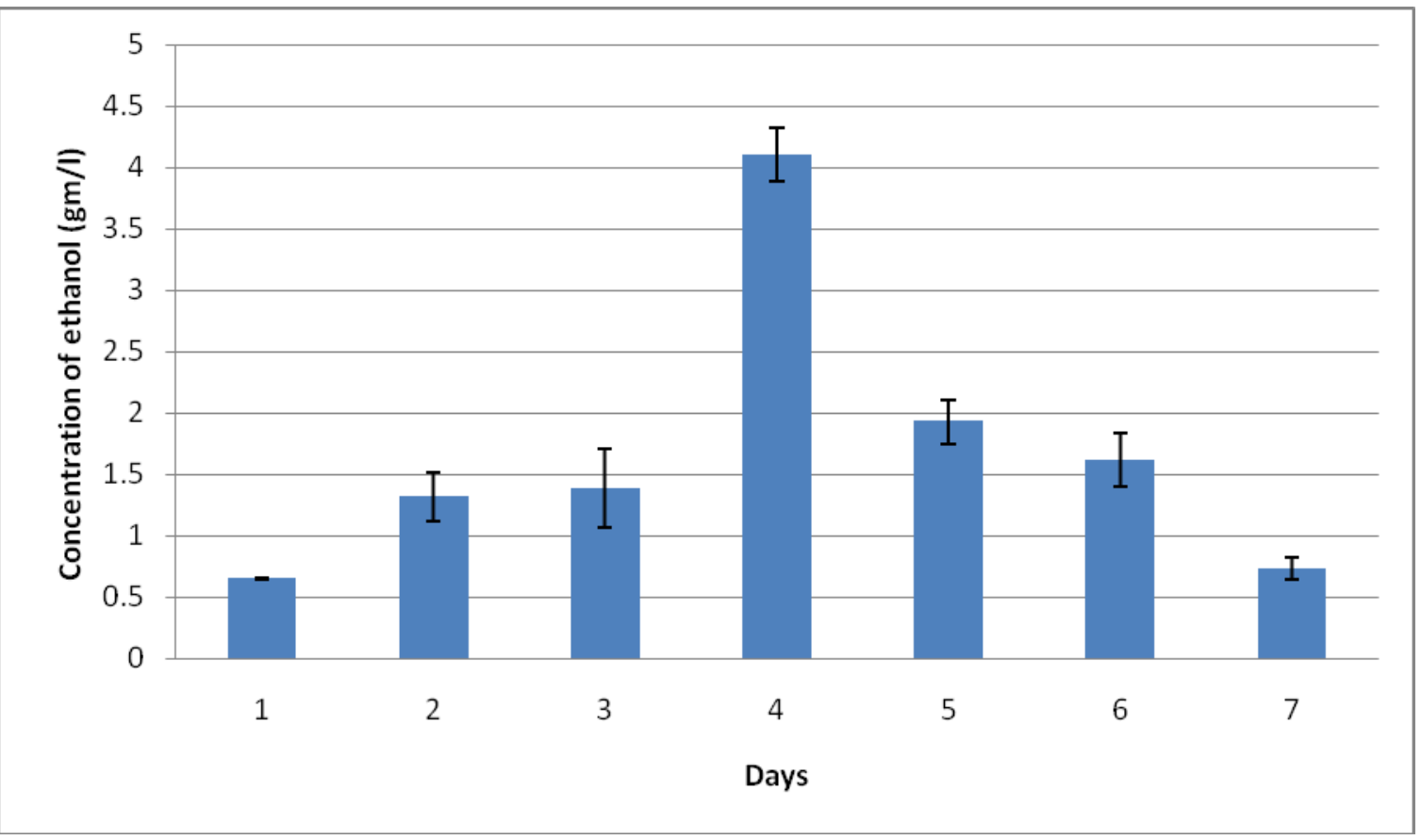


Fig.2 Amount of ethanol production vs days graph by N3 (Bacillus stearothermophilus)

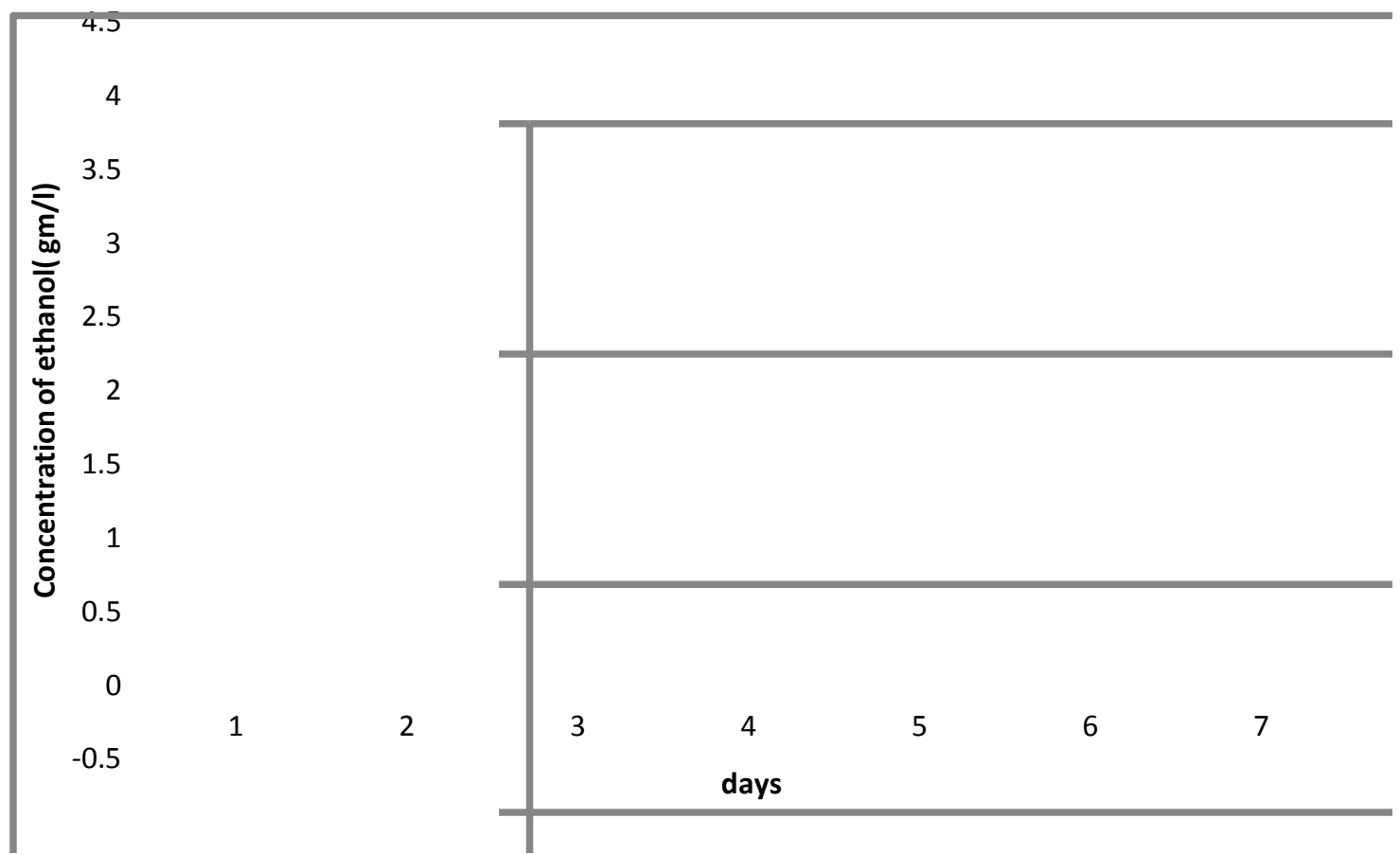

Fig.3 Amount of ethanol production vs days graph by N2 (Bacillus vietnamensis)

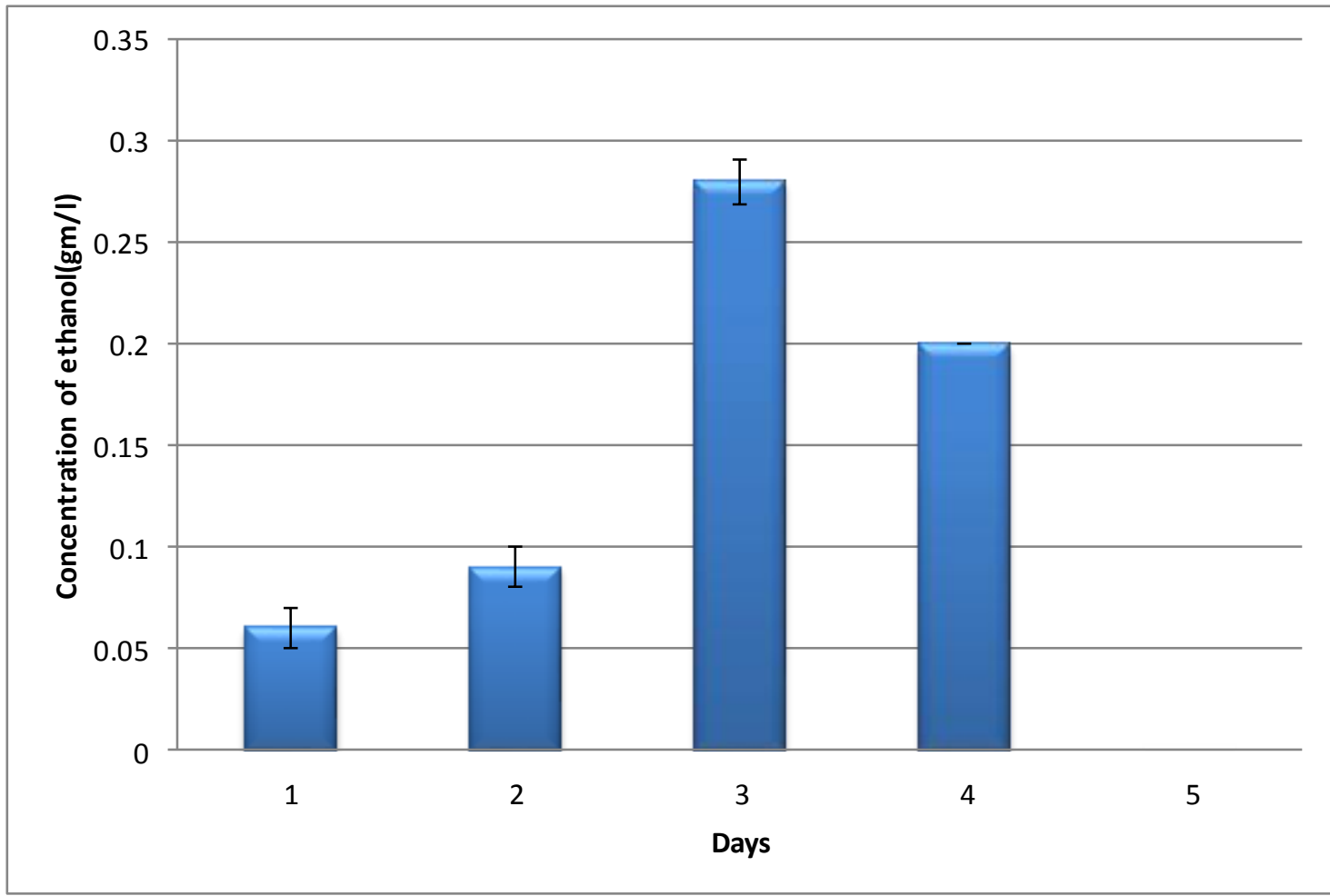


Fig.4 Amount of ethanol produced vs days by N3 (Bacillus stearothermophilus)

2.5

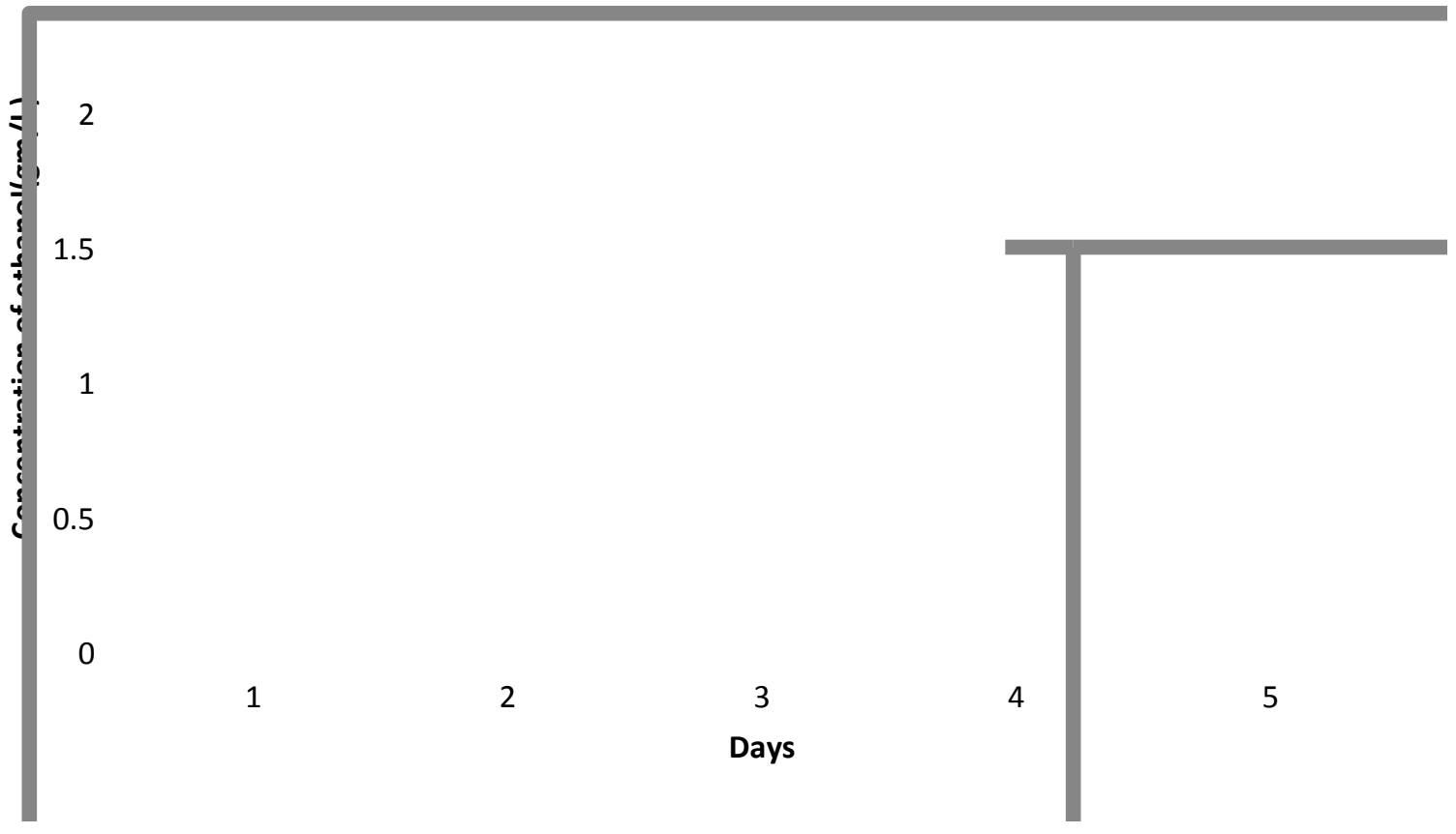

Fig.5 Comparative analysis of ethanol produced by acid and alkali pretreatment

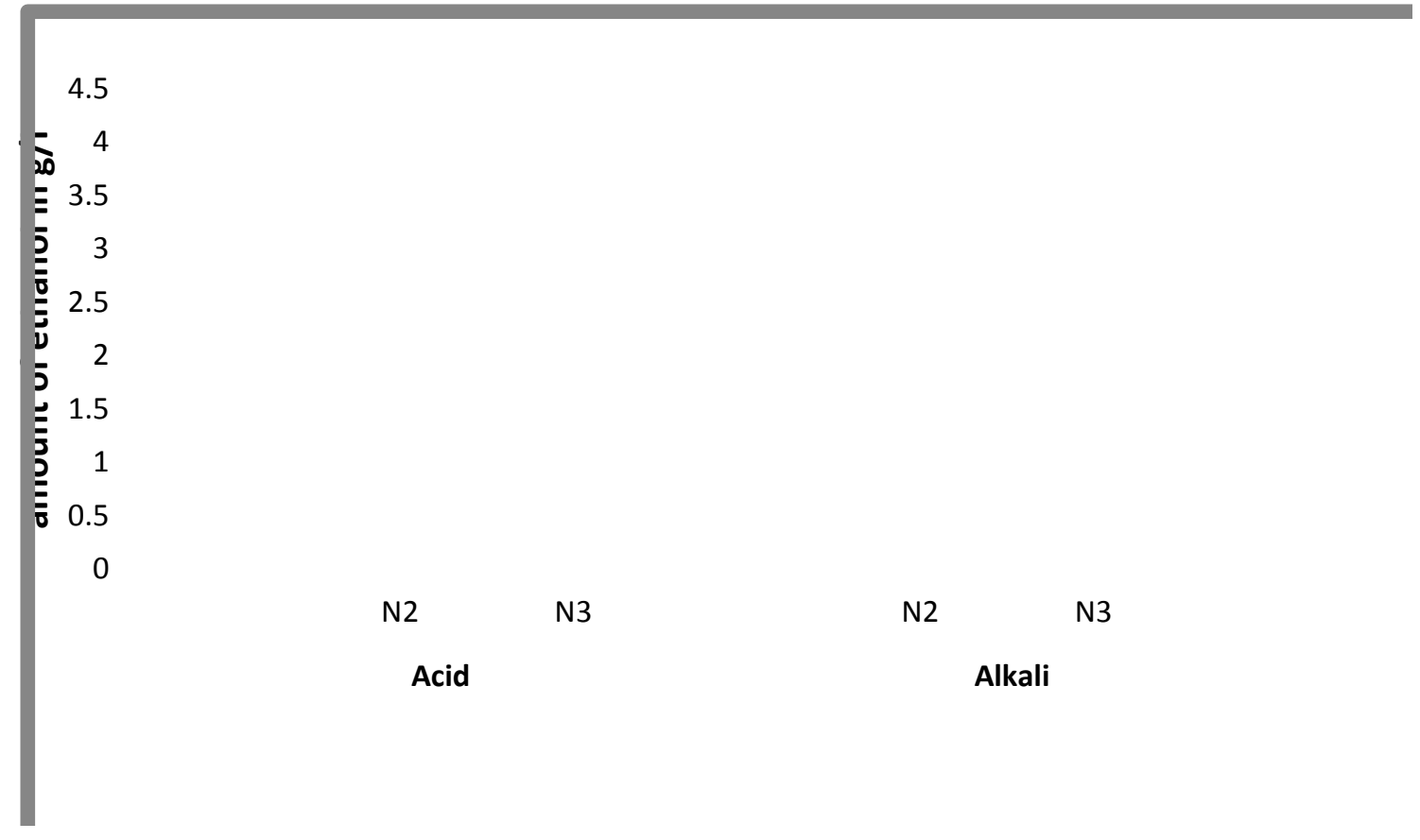


However, in our study acid pretreated water hyacinth substrate produced a maximum of 4.1 $\mathrm{gm} / 1$ ethanol on $4^{\text {th }}$ day by $\mathrm{N} 2$ (Bacillus vietnamensis) strain and $3.58 \mathrm{gm} / 1$ by $\mathrm{N} 3$ (Bacillus stearothermophilus) on $5^{\text {th }}$ day.

The alkali pretreated water hyacinth substrate produced a maximum of $0.28 \mathrm{gm} / 1$ ethanol on $3^{\text {rd }}$ by $\mathrm{N} 2$ (Bacillus vietnamensis) and $2.12 \mathrm{~g} / \mathrm{l}$ by $\mathrm{N} 3$ (Bacillus stearothermophilus) on $2^{\text {nd }}$ day.

So acid pretreatment was the most eff ective method for bioethanol production by water hyacinth compared to alkali pretreatment method.

Water hyacinth (Eichhornia crassipes) is one of the world's worst aquatic weeds and it infests rivers, dams, lakes and canals all over the world so it affects the aquatic environment which is a worldwide problem. In the present study we were used this aquatic waste (water hyacinth) as a substrate for bioethanol production to overcome this problem. Bioethanol is one of the most promising replacement for fossil fuel as it is renewable and releases $85 \%$ less green-house gases compared to gasoline.

\section{Acknowledgement}

We would like to thank Codon Biotech for providing the infrastructure and laboratory premises and all other support for carrying out the present study. The whole study has been carried out in Codon Biotech laboratories.

\section{References}

Bayrakci A. G. and Koçar G. (2014).Secondgeneration bioethanol production from water hyacinth and duckweed in Izmir: a case study. Renew. Sustain. Energy Rev.30, 306-316.

Chum, L.H., R.P Overend (2001) Biomass and renewable fuels, Fuel Bioprocess Technology 17, 187-195.

Das S., Bhattacharya A., Haldar S., Ganguly A., Gu S., Ting Y. P. (2015). Optimization of enzymatic saccharification of water hyacinth biomass for bio-ethanol: comparison between artificial neural network and response surface methodology. Sustain. Mater. Technol., 3, 17-28.

Ganguly A., Chatterjee P. K., and Dey A. (2012) Studies on ethanol production from water hyacinth-A review.ll, Renewable and Sustainable Energy Reviews, 16, 966-972.

Guerrero-Coronilla I., Morales-Barrera L., Cristiani-Urbina E. (2015). Kinetic, isotherm and thermodynamic studies of amaranth dye biosorption from aqueous solution onto water hyacinth leaves. J. Environ. Manage.152, 99-108.

Hu. J., Arantes J., Saddler J.N. (2011). The enhancement of enzymatic hydrolysis of lignocellulosic substrates by the addition of accessory enzymes such as xylanase: is it an additive or synergistic effect, Biotechnology for Biofuels, 4: 36.

Kumari N, Bhattacharya A, Dey A, Ganguly A, Chatterjee P.K (2014) Bioethanol production from water hyacinth biomass using isolated fungal strain from local environment. Biolife, Vol 2 | Issue 2: 516-522.

Malik A. (2007). Environmental challenge vis a vis opportunity: the case of water hyacinth. Environ.Int.33, 122-138.

Miller, G. L. (1959) "Use of dinitrosalicylic acid reagent for determination of reducing sugar", Analytical Chemistry, 31, 426428.

Mishima D, Kuniki M, Sei K, Soda S, Ike M, Fujita M. (2008) Ethanol production from candidate energy crops: Water hyacinth (Eichhornia crassipes) and water lettuce (Pistia stratiotes L.). Bioresour Technol 99(7):2495-500.

Nigam J. N., (2002) Bioconversion of waterhyacinth (Eichhornia crassipes) hemicellulose acid hydrolysate to motor fuel ethanol by xylose-fermenting yeast. J. Biotechnol. 97, 107-111.

Qiuzhuo Zhang, Chen Weng, Huiqin Huang, Varenyam Anchal and Duanchao Wang. (2016) Optimization of Bioethanol 
Production Using Whole Plant of Water Hyacinth as Substrate in Simultaneous Saccharification and Fermentation Process. Frontiers in Microbiology. Volume 6, Article 1411.

Rezania S., Ponraj M., Md Din M. F., Songip A. R., Sairan F. M., Chelliapan S. (2015). The diverse applications of water hyacinth with main focus on sustainable energy and production for new era: an overview. Renew. Sustain. Energy Rev.41, 943-954.

Valentine J., Clifton-Brown J., Hastings A., Robson P., Allison G., Smith P. (2012). Food vs. fuel: the use of land for lignocellulosic 'next generation' energy crops that minimize competition with primary food production. Global Change Biol. Bioenergy. 4, 1-19.

\section{How to cite this article:}

Preetha Ganguly, Chetna Gangwar, Anurag Mishra, Rosy Rani, Shashank Awasthi, Ravi Kant Singh and Tripti Bhatnagar. 2018. Effect of Saccharification Methods on Bioethanol Production by Thermophiles from Eichhornia crassipes. Int.J.Curr.Microbiol.App.Sci. 7(02): 3595-3603. doi: https://doi.org/10.20546/ijcmas.2018.702.428 